\title{
Total phenolic content, antioxidant activity and organoleptic test of Nata de pina between various parts of honey pineapple variety (Ananas comosus [L.] Merr. Var. Queen)
}

\author{
${ }^{1}$ Sari, D.Y.I., ${ }^{1,2}$ Wijayanti, H.S. and ${ }^{1,2^{*}}$ Afifah, D.N. \\ ${ }^{1}$ Department of Nutrition Science, Faculty of Medicine, Universitas Diponegoro, Jl. Prof H. Soedarto, SH, \\ Tembalang, Semarang 50275, Indonesia \\ ${ }^{2}$ Center of Nutrition Research (CENURE), Universitas Diponegoro, Jl. Prof H. Soedarto, SH, Tembalang, \\ Semarang 50275, Indonesia
}

Article history:

Received: 29 December 2019

Received in revised form: 14

February 2020

Accepted: 4 June 2020

Available Online: 11 July

2020

\section{Keywords:}

Nata de pina,

Honey pineapple variety,

Total phenolic content,

Antioxidant activity

\section{DOI:}

https://doi.org/10.26656/fr.2017.4(S3).S05

\begin{abstract}
This study was aimed to analyze the total phenolic content, antioxidant activity and organoleptic properties of Nata de pina between various parts of honey pineapple variety (Ananas comosus [L.] Merr. Var. Queen). This study was a two - factors randomized experimental study with variations of Nata de pina from fruit peel, fruit flesh, fruit core, and fermentation processing. Folin-Ciocalteu reagent was used to analyze the total phenolic content and 2,2'-diphenyl-1-Picrylhydrazy (DPPH) assay was used to determine the antioxidant activity. The total phenolic content of Nata de pina ranged from 102.37$249.99 \mathrm{mg}$ of GAE/100 $\mathrm{g}$ of samples while the $\mathrm{IC}_{50} \mathrm{DPPH}$ ranged from 101.71-555.45 ppm. There was a difference of the total phenolic content and antioxidant activity of the juice and Nata de pina produced from different parts of the fruit. Fruit core Nata de pina presented the highest content of the total phenolic content and antioxidant activity. There were significant differences in the organoleptic tests viz color $(\mathrm{p}=0.030)$, flavor $(\mathrm{p}<0.001)$, texture $(\mathrm{p}<0.001)$. Fruit flesh Nata de pina had the highest organoleptic score. Overall, based on result of this study, fruit core Nata de pina was recommended as the best product based on the high total phenolic content (139.88 mg GAE/100 g), antioxidant activity $(263.38 \mathrm{ppm})$ and well-liked panelists based on the acceptance of aroma and color.
\end{abstract}

\section{Introduction}

Cardiovascular disease is a disease caused by impaired cardiac and vascular function. Most cardiovascular diseases are accompanied by increased oxidative stress in the body. Oxidative stress caused by excessive production of free radicals or lack of antioxidants. Free radicals are molecules that contain one or more electrons not paired in their outer layers, so one of them can be stabilized by antioxidant by completing the lack of electrons. If the number of free radicals are not sufficient, then the body will utilize antioxidants from food (Go et al., 2014; Kehrer and Klotz, 2015; Cervantes Gracia et al., 2017). Many foods in Indonesia contain antioxidants especially fruits. Pineapple (Ananas comosus [L.] Merr.) is one of Indonesia's local fruits with increasing production. The Queen variety is widely found in Indonesia and the Honey pineapple variety (Ananas comosus [L.] Merr. Var. Queen), a subspecies of the Queen variety, contains natural antioxidants in every parts of its fruit such as phenolic compounds, flavonoids, vitamin $\mathrm{C}$, vitamin $\mathrm{E}$, and others.
Antioxidant activity between various parts of honey pineapple variety such as flesh, peel, bract, and core ranged from 0.13 to $68.17 \mu \mathrm{g} / \mathrm{mL}$ (Fidrianny et al., 2018). In addition, the total phenolic content differs in each part of the fruit such as P-coumaric acid, ferulic acid, caffeic acid, sinapic acid, P-coumaroyl quinic acid, P-hydroxybenzoic acid, and P-hydroxy benzoic aldehydes in the fruit skin, while catechins, epicatechin, gallic acid, and ferulic acid found in the fruit peel. The total phenolic content ranged from $71.07 \mathrm{mg}$ of gallic $\mathrm{acid} / 100 \mathrm{~g}$ to $126.95 \mathrm{mg}$ gallic acid/100 g (Hassan et al., 2011; Ferreira et al., 2016).

Honey pineapple variety has the potential to be used as a raw material for Nata de pina production. Nata is a cellulose formed by Acetobacter xylinum. Generally, Nata is made from fermented coconut water, but the juice of various parts of honey pineapple variety such as peel, core, and fruit flesh can also be used as fermentation medium in making nata. These parts are known to contain organic acids and minerals that can accelerate the growth of $A$. xylinum. Besides, producing 
Nata de pina is one of the ways to utilize the peel and other underutilized parts of the fruit that is seldom or not consumed by people (Almeida et al., 2013). Utilization of the various fruit parts of honey pineapple variety may increase the nutrient content such as total phenolic content, antioxidants activity, and improved appearance. However, the heating process in processing Nata de pina is known to affect the total phenolic content and antioxidant activity (Nayak et al., 2015). Therefore, this study was conducted to analyze the total phenolic content, antioxidant activity and organoleptic test in Nata de pina made from the various fruit parts of honey pineapple variety as an alternative food with good quality and flavor.

\section{Materials and methods}

\subsection{Sample}

Juice of the various parts of the honey pineapple variety (peel, flesh and core) and Nata de pina prepared using the juice of the respective fruit parts were analyzed as samples. The juice represents the pre-fermentation product while the Nata de pina represents the fermented product. Honey pineapple were obtained from the district of Belik, the regency of Pemalang, Central Java, Indonesia. The characteristics of the fruits used are 5 to 6 months, large and round, open fruit crown, wrinkle stem, flatter bract fruit with yellow base and a distinctive smell of pineapple.

\subsection{Nata de pina preparation}

The juices from the peel, flesh and core are each mixed with water at the ratio of fruit juice: water $=1: 2$ was prepared as the fermentation media. The mixture was heated and added with $7.5 \%$ sucrose and $0.5 \%$ urea. Then, glacial acetic acid was added to adjust the $\mathrm{pH}$ to 4 and stirred slowly until the temperature reached $100^{\circ} \mathrm{C}$. The fermentation medium was poured onto a $20 \times 40 \times 5$ $\mathrm{cm}$ plastic pan and covered to allow to cool to room temperature $\left(28-31^{\circ} \mathrm{C}\right)$ for $12 \mathrm{hrs}$. Aseptically, $10 \%$ starter culture of $A$. xylinum was inoculated into the fermentation medium. The fermentation process was carried out for 8 days in a dark room at room temperature.

After 8 days, the formed Nata de pina was cut and soaked for 2 days in marinated water which is replaced twice a day. Next, the soaked Nata de pina was boiled for 15 mins in a sugar solution $(5 \mathrm{~g} / \mathrm{L})$ (Sutanto, 2012). The Nata de pina was then freeze-dried at $-50^{\circ} \mathrm{C}, 0.03$ $\mathrm{hPa}$ using a freeze dryer (Power Dry LL 1500) until the moisture content was below 5\% (Pa'e et al., 2014) to retain the content of Nata nutrients.

\subsection{Determination of total phenolic content (TPC)}

TPC using the Folin Ciocalteu assay was carried out according to existing protocols in the laboratory as described by Musci et al. (2017). The Folin-Ciocalteu solution was prepared by diluting the $2 \mathrm{M}$ FolinCiocalteu reagent (Sigma-Aldrich, Milan, Italy) with distilled water at the ratio of $1: 10(\mathrm{v} / \mathrm{v})$. A $10 \%(\mathrm{w} / \mathrm{v})$ $\mathrm{Na}_{2} \mathrm{CO}_{3}$ solution was prepared by diluting pure $\mathrm{Na}_{2} \mathrm{CO}_{3}$ (Sigma-Aldrich, Milan, Italy) with distilled water. In the reaction tubes, $\mathrm{Na}_{2} \mathrm{CO}_{3}(1 \mathrm{~mL})$ was added to each Nata de pina sample $(250 \mu \mathrm{L})$. After 5 mins, Folin Ciocalteu reagent $(1 \mathrm{~mL})$ was added. After 120 mins incubation at $25^{\circ} \mathrm{C}$, protected from light, the absorbance was measured at $765 \mathrm{~nm}$ using a UV-Vis spectrophotometric. The analysis was carried out in triplicates. The total phenolic contents in all samples was calculated the using the formula: $\mathrm{C}=\mathrm{c} \times \mathrm{V} / \mathrm{m}$ where, $\mathrm{C}=$ total phenolic content mg GAE/ $100 \mathrm{~g}$ sample, $\mathrm{c}=$ concentration of gallic acid obtained from calibration curve in $\mathrm{mg} / \mathrm{mL}, \mathrm{V}=$ volume measured at the spectrophotometer in $\mathrm{mL}, \mathrm{m}=$ mass of sample in $\mathrm{g}$.

Results were expressed in milligram gallic acid equivalents per $100 \mathrm{~g}$ of sample (mg GAE/ $100 \mathrm{~g}$ sample). Working standard solutions of gallic acid at eight different concentration levels $(0,2,4,6,8,10,12$ and $14 \mu \mathrm{g} / \mathrm{mL}$ ) were prepared by diluting the stock solution and measured the absorbance to build a calibration curve. All the standard solutions were stored at $4^{\circ} \mathrm{C}$ until analysis (Musci and Yao, 2017).

\subsection{Determination of antioxidant activity}

The antioxidant capacity of each sample was determined using the 2,2'-diphenyl-1-picrylhydrazy (DPPH) radical scavenging capacity assay according to Sami et al. (2015). DPPH radical solution $(0.4 \mathrm{mM}$ in methanol) of $1 \mathrm{~mL}$ was added to the sample. After 30 mins incubation in darkness at $30^{\circ} \mathrm{C}$, the absorbance was measured at $517 \mathrm{~nm}$ by UV-Vis spectrophotometer. The analysis was carried out in triplicates. Methanol was used as blank and DPPH $50 \mu \mathrm{g} / \mathrm{mL}$ as control. Antioxidant activity was presented as inhibitory concentration $50 \%\left(\mathrm{IC}_{50}\right)$ of $\mathrm{DPPH}$ scavenging activity by calculating $\mathrm{IC}_{50}$ of each extract using a calibration curve of five different concentration levels $(80,100,120$, 140 and 160 ppm) (Sami and Rahimah, 2015).

\subsection{Determination of organoleptic test}

The organoleptic test of Nata de pina using hedonic tests including color, aroma, flavor, and texture were carried out on twenty-five semi-trained panelists with 5point hedonic scale, i.e. $1=$ very dislike to $5=$ very fond. The best-recommended product selected based on the 
effectiveness index using the modified De Garmo method by Susrini (2005). Determination of the bestrecommended product starts by assigning a variable weight (BV) of $0-1$ to each parameter based on its importance. The normal weight $(\mathrm{BN})$ is determined on each parameter from the division of the variable weight per treatment by the total variable weights of all treatments. The value of effectiveness (NE) is obtained by comparing the difference in the value of treatment (NP) and the worst value with the difference of the best and worst value. Yield value $(\mathrm{NH})$ is determined by the multiplication value of the effectiveness with the normal weight then sum. The highest total yield value treatment was considered the best-recommended product in this study (Susrini, 2005).

\subsection{Statistical analysis}

Data were presented as mean with standard deviation. The normality of data distribution was tested by the Shapiro-Wilk method. The total phenolic content and antioxidant activity before and after the fermentation was analyzed using the T-test in pairs (Pair T-tests), while the treatment was analyzed using the One way ANOVA test for normal distribution data and test Kruskal-Wallis for irregular distribution data is continued with Tukey's advanced test to find out the real difference between treatment. Organoleptic Test Data was analyzed using the Kruskal-Wallis test and continued with the Mann-Whitney advanced test to determine the apparent difference between treatment (Sugiyono, 2015)

\section{Results and discussion}

\subsection{Total phenolic content (TPC) and antioxidant activity}

The total phenolic content (TPC) in Table 1 presented statistically significant differences between the different fruit parts' juices $(\mathrm{p}<0.001)$ and in the samples of Nata de pina $(\mathrm{p}=0.016)$. However, the TPC showed significant reductions in samples of Nata de pina from the juice. The highest TPC value obtained was from the fruit core whether in juice (249.99 mg GAE/100 g) or Nata de pina (139.88 mg GAE/100 g) (Hassan et al., 2011; Ferreira et al., 2016). The significant difference in the fruit parts' juices and Nata de pina was due to the presence of other sources of natural antioxidants that are different in each part of the fruit. It is known that the core of pineapple honey had a higher content of oxalic acid, another source of antioxidant. Oxalic acid is a common constituent of plants and some species. Oxalic acid is known to have a strong chelating ability with cations. Previous studies had explained that oxalic acid can inhibit the formation of hydroxyl radicals and lipid peroxidation, as well as reduced the rate of ascorbic oxidation through the process of compression by the presence of hydrogen peroxide and $\mathrm{Cu}^{(2+)}$. These results indicated that oxalic acid can be a natural antioxidant, but the availability of antioxidant capacity in oxalic acid is unclear (Kayashima and Katayama, 2002).

Table 1. Total phenolic content (TPC)

\begin{tabular}{|c|c|c|c|}
\hline \multirow[b]{2}{*}{$\begin{array}{l}\text { Fruit } \\
\text { Parts }\end{array}$} & \multicolumn{2}{|c|}{ Total Phenolic Content } & \multirow[b]{2}{*}{$P^{\#}$} \\
\hline & $\begin{array}{c}\text { Juice } \\
\text { Mean } \pm \text { SD } \\
\text { (mg GAE } / 100 \mathrm{~g} \\
\text { samples) }\end{array}$ & $\begin{array}{c}\text { Nata } \\
\text { Mean } \pm \text { SD } \\
\text { (mg GAE } / 100 \mathrm{~g} \\
\text { samples) }\end{array}$ & \\
\hline Peel & $153.82 \pm 2.48^{\mathrm{b}}$ & $102.37 \pm 5.38^{\mathrm{b}}$ & $0.001^{\mathrm{x}}$ \\
\hline Flesh & $198.12 \pm 6.14^{\mathrm{c}}$ & $115.13 \pm 5.20^{\mathrm{c}}$ & $0.006^{\mathrm{x} *}$ \\
\hline Core & $249.99 \pm 7.23^{\mathrm{d}}$ & $139.88 \pm 2.51^{\mathrm{d}}$ & $0.003^{\mathrm{x} *}$ \\
\hline$p$ & $<0.001^{\mathrm{y} *}$ & $0.016^{\mathrm{Z} *}$ & \\
\hline
\end{tabular}

${ }^{\#}$ Analyzed via Paired T-test, ${ }^{\mathrm{y}}$ Analyzed via one-way ANOVA, ${ }^{\mathrm{z}}$ Analyzed via Kruskal Wallis Test. Different superscrip letters in the same column showed significant differences $(\mathrm{p}<0.05)$.

The results of antioxidant activity measured by the DPPH assay was presented in Table 2. Statistically significant difference in the group of fruit part's juices $(\mathrm{p}<0.001)$ and Nata de pina $(\mathrm{p}<0.001)$. The highest antioxidant activity was found in the fruit core where the juice and Nata de pina had $\mathrm{IC}_{50} 101.71$ and $263.28 \mathrm{ppm}$, respectively. An increase in the antioxidant activities was observed when Nata de pina was produced from the juice of the fruit parts. The decrease in the content was related to the processing of Nata de pina where thermal treatment was involved to kill pathogenic bacteria and other contaminants before fermentation and subsequently the produced Nata de pina was re-heated to make the texture supple (Sutanto, 2012).

Table 2. Antioxidant activity

\begin{tabular}{cccc}
\hline & \multicolumn{2}{c}{ Antioxidant activity } & \\
\cline { 2 - 3 } Fruit & Juice & $p^{x}$ \\
Parts & $\begin{array}{c}\text { Nata de pina } \\
\text { Mean } \pm \text { SD }(\mathrm{ppm})\end{array}$ & Mean \pm SD $(\mathrm{ppm})$ & \\
\hline Peel & $197.22 \pm 7.08^{\mathrm{b}}$ & $555.45 \pm 30.87^{\mathrm{b}}$ & $0.003^{*}$ \\
Flesh & $126.70 \pm 9.22^{\mathrm{c}}$ & $441.89 \pm 26.78^{\mathrm{c}}$ & $0.001^{*}$ \\
Core & $101.71 \pm 1.00^{\mathrm{d}}$ & $263.38 \pm 9.02^{\mathrm{d}}$ & $0.001^{*}$ \\
\hline$p^{y}$ & $<0.001^{*}$ & $<0.001^{*}$ & \\
\hline
\end{tabular}

${ }^{\mathrm{x}}$ Analyzed via paired T-test, ${ }^{\mathrm{y}}$ Analyzed via one-way ANOVA. Different superscript letters in the same column showed significant differences $(\mathrm{p}<0.05)$.

Fermentation process is known to increase the TPC and antioxidant activity. During the fermentation process, A. xylinum thrives in the acidic environment in the media by converting glucose into gluconate acid and fructose into acetic acid. This causes the concentration of organic acids contained in the media to increase, thereby increasing the medium phenolic compounds and 
eventually increases the antioxidant activity. The fermentation process could have increased the TPC and antioxidant activity slightly (Pothakos et al., 2016), but might be counter-destroyed during the thermal process as shown in the results of this study.

Some research showed different results regarding temperature and prolonged heating on the TPC. In the previous studies, the temperature and long-cooking high during processing can essentially increase the TPC. The increase in TPC is caused by the release of the phenol compounds on the cell wall. However, the TPC began to decrease at a temperature of $104-105^{\circ} \mathrm{C}$ from several varieties of cherries and plums. In this research, the water temperature was not measured during the heating process. The indicator used were only boiling water at a temperature of $100^{\circ} \mathrm{C}$ at the beginning of heating of Nata de pina heating as well as time. Based on the process, the significant reduction could have started when the Nata de pina was heated due to the heating factor and the solubility of phenol in boiling water. The decrease of the TPC during cooking can occur by two processes through dissolving in the processing fluid and through oxidation. The TPC can be oxidized by the activity of the polyphenol oxidase enzyme thereby forming a reactivesemiquinone radical ortho. Due to the direct heating in boiling water, the cell walls and plasma membrane suffered quicker damage allowing water to insert into the cell wall and vacuoles and dissolving the phenol compounds into the processing fluid (Srinivas et al., 2010; Aisyah et al., 2015).

Antioxidant activities decreased after the heating process when making the product, this caused the value of $\mathrm{IC}_{50}$ to increase in the samples of Nata de Pina. The heating process during processing can cause the degradation of natural antioxidants contained in honey pineapple variety fruit thereby accelerating the oxidation of antioxidant compounds. The oxidation process can be accelerated by the presence of heat, rays, alkali, enzymes, oxidizing agents, by copper and iron catalysts. The heating process with a temperature of $60^{\circ} \mathrm{C}$ for 30 mins can decrease $10 \%$ antioxidant capacity in some types of fruits. In this study, the TPC and antioxidant activity were relatively low after the processing of Nata de pina.

\subsection{Organoleptic test}

The results of organoleptic test in Table 3 presented statistically significant difference in the color acceptance $(p=0,030)$, flavor $(p<0.001)$ and texture $(p<0.001)$, but not significant in the aroma $(\mathrm{p}=0.955)$. Fruit peel Nata de pina and fruit flesh Nata de pina indicated neutral or almost liked appearance by the panelist. Fruit core Nata de pina presented neutral or almost liked by the panelist in the color and aroma assessment but was less liked in the flavor and texture. The color of Nata de pina showed almost the same appearance that is slightly yellowishwhite. The white color is produced due to of A. xylinum. The bacteria produce a compliable enzyme into a chain of sugar or cellulose fibers from the millions of biomass planted on the substrate, then will produce millions of cellulose yarn pieces and produce a solid white-looking coating to transparent (Nugroho and Aji, 2015).

The aroma of Nata de pina showed insignificant difference between all the samples of Nata de pina. This is due to the similarity of the distinctive aroma of the Nata de pina, which is a typical acid-scented fermentation. During fermentation, the precursor to flavor and aroma develops and the pigment is degraded by enzymes such as invertases, glycosidase, protease, and polyphenol oxidase. Fermentation affects the decline of compounds such as sugar, peptides, and amino acids, which are converted into flavor and smell profiles (Anal, 2019). The immersion process in the Nata de pina production is known to reduce the acid smell of Nata de pina produced. This process can eliminate the effects of acetic acid added to the fermentation medium during the processing and does not affect the flavour (Asri et al., 2018).

The indicator of flavor showed a significantly difference, but only in the fruit core Nata de pina. According to panelists, fruit core Nata de pina had a very bland flavor. Fruit flesh Nata de pina had the highest acceptance. The variation of the resulting flavor arose from the acidic flavor due to the fermentation process. Texture indicators showed some variations from easily chewed and swallowed until hard to chew and swallow. The variation is influenced by the processing of basic materials and the fermentation process by $A$. xylinum. A. xylinum produce cellulose which will make

Table 3. Organoleptic test

\begin{tabular}{ccccccccc}
\hline \multirow{2}{*}{ Fruit Parts } & \multicolumn{2}{c}{ Color } & \multicolumn{2}{c}{ Aroma } & \multicolumn{2}{c}{ Flavor } & \multicolumn{2}{c}{ Texture } \\
\cline { 2 - 8 } & Mean \pm SD & Category & Mean \pm SD & Category & Mean \pm SD & Category & Mean \pm SD & Category \\
\hline Peel & $3.44 \pm 1.39^{\mathrm{b}}$ & Neutral & $3.20 \pm 0.71$ & Neutral & $3.68 \pm 0.99^{\mathrm{a}}$ & Neutral & $3.72 \pm 0.89^{\mathrm{ab}}$ & Neutral \\
Flesh & $3.76 \pm 0.97^{\mathrm{ab}}$ & Neutral & $3.08 \pm 0.86$ & Neutral & $3.92 \pm 1.00^{\mathrm{a}}$ & Neutral & $3.48 \pm 1.39^{\mathrm{b}}$ & Neutral \\
Core & $3.96 \pm 0.98^{\mathrm{ab}}$ & Neutral & $3.20 \pm 0.65$ & Neutral & $2.76 \pm 1.13^{\mathrm{b}}$ & Dislike & $2.96 \pm 1.46^{\mathrm{b}}$ & Dislike \\
\hline$p^{*}$ & 0.03 & & 0.955 & & $<0.001$ & & $<0.001$ & \\
\hline
\end{tabular}

*Analyzed via Kruskal Wallis Test. Different superscript letters in the same column showed significant differences $(\mathrm{p}<0.05)$ 
the smooth surface of Nata de pina. A texture that has the highest acceptance is the fruit peel Nata de pina (Phong et al., 2017).

\subsection{The best-recommended product}

The results of the best-recommended product in Table 4 had confirmed that fruit core Nata de pina had the highest value (Index effectiveness $=0.696$ ) compared to other parts of the fruit. Fruit peel Nata de pina had the lowest value. The best-recommended product had the highest TPC (139.88 mg GAE/100 g), antioxidant activity (263.38 ppm) and well-liked panelists based on the acceptance of aroma, color despite less liked for the flavors and textures. Product evaluation considers all variables to determine the product quality including the TPC, antioxidant activity and organoleptic tests. The flavor can be improved with the addition of low-calorie natural sweeteners in the syrup when packing the product.

Table 4. The best-recommended product

\begin{tabular}{cc}
\hline Samples & Index effectiveness \\
\hline Peel & 0.493 \\
Flesh & 0.512 \\
Core & 0.696 \\
\hline
\end{tabular}

\section{Conclusion}

Nata de pina produced of the various fruit parts of honey pineapple variety had a difference in the total phenolic content and antioxidant activity. The waste of the fruit such as the peel and the core of honey pineapple variety can be utilized to produce Nata de pina. Nata de pina produced of the various fruit parts of honey pineapple variety gave a significant difference to the level of acceptance of color, flavor, and texture. The fruit core Nata de pina is the best product recommended based on the results of the analysis of the total phenolic content, antioxidant activities as well as organoleptically.

\section{Conflict of interest}

The author declares no conflict of interest. The authors alone are responsible for the content and writing of this article.

\section{Acknowledgments}

The authors acknowledged the Ministry of Research and Higher Education, the Republic of Indonesia for financial support during preparing this article.

\section{References}

Aisyah, Y., Rasdiansyah. and Muhaimin. (2015). Effect of Heating on Antioxidant Activity of Some Vegetables. Jurnal Teknologi dan Industri Pertanian
Indonesia, 6(2), 28-32. https://doi.org/10.17969/ jtipi.v6i2.2063 [In Bahasa Indonesia]

Almeida, D.M., Prestes, R.A., Fonseca, A.F.D., Woiciechowski, A.L. and Wosiacki, G. (2013). Minerals consumption by Acetobacter xylinum on cultivation medium on coconut water. Brazilian Journal of Microbiology, 44(1), 197-206. https:// doi.org/10.1590/S1517-83822013005000012

Anal, A. (2019). Quality Ingredients and Safety Concerns for Traditional Fermented Foods and Beverages from Asia: A Review. Fermentation, 5(1), 8. https://doi.org/10.3390/fermentation5010008

Asri, M.T., Ducha, N., Ratnasari, E. and Bashri, A. (2018). Application of Acetobacter xylinum in the Production of Nata de Legen from Palmyra Palm Neera. Journal of Physics: Conference Series, 1108 (1), 012098. https://doi.org/10.1088/1742$6596 / 1108 / 1 / 012098$

Cervantes Gracia, K., Llanas-Cornejo, D. and Husi, H. (2017). CVD and oxidative stress. Journal of Clinical Medicine, 6(2), 22, 1-13. https:// doi.org/10.3390/jcm6020022

Ferreira, E.A., Siqueira, H.E., Boas, E.V.V., Hermes, V.S. and Rios, A.D.O. (2016). Bioactive Compounds and Antioxidant Activity of Pineapple Fruit of Different Cultivars. Revista Brasileira de Fruticultura, 38(3), 1-7. https:// doi.org/10.1590/0100-29452016146

Fidrianny, I., Virna, V. and Insanu, M. (2018). Antioxidant Potential of Different Parts of Bogor Pineapple (Ananas Comosus [L.] Merr. Var. Queen) Cultivated in West Java-Indonesia. Asian Journal of Pharmaceutical and Clinical Research, 11(1), 129133. ajpcr.2018.v11i1.22022

Go, A.S., Roger, V.L., Benjamin, E.J., Berry, J.D., Blaha, M.J., Dai, S., Ford, E.S., Fox, C.S., Franco, S., Fullerton, H.J., Gillespie, C., Hailpern, S.M., Heit, J.A., Howard, V.J., Huffman, M.D., Judd, S.E., Kissela, B.M., Kittner, S.K., Lackland, D.T., Lichtman, J.H., Lisabeth, L.D., Mackey, R.H., Magid, D.J, Marcus, G.M., Marelli, A., Matchar, D.B., McGuire, D.K., Mohlerlll, E.R., Moy, C.S., Mussolino, M.E., Neumar, R.W., Nichol, G.., Pandey, D.K., Paynter, N.P., Reeves, M.J., Sorlie, P.D., Stein, J., Towfighi, A., Turan, T.N., Virani, S.S., Wong, N.D., Woo, D. and Turner, M.B. (2014). Heart disease and stroke statistics--2014 update: a report from the American Heart Association. Circulation, 129(3), e28-e292. https:// doi.org/10.1161/01.cir.0000441139.02102.80

Hassan, A., Othman, Z. and Siriphanich, J. (2011). Pineapple (Ananas conosus L. Merr.). In Yahia, 
E.M. (Ed.). Postharvest Biology and Technology of Tropical and Subtropical Fruits, p. 194-217. USA: Woodhead Publishing.

Kayashima, T. and Katayama, T. (2002). Oxalic acid is available as a natural antioxidant in some systems. Biochimica et Biophysica Acta - General Subjects, 1573(1), 1-3. https://doi.org/10.1016/S0304-4165 (02)00338-0

Kehrer, J.P. and Klotz, L.-O. (2015). Free radicals and related reactive species as mediators of tissue injury and disease: implications for Health. Critical Reviews in Toxicology, 45(9), 765-798. https:// doi.org/10.3109/10408444.2015.1074159

Musci, M. and Yao, S. (2017). Optimization and validation of Folin-Ciocalteu method for the determination of total polyphenol content of Pu-erh tea. International Journal of Food Sciences and Nutrition, 68(8), 913-918. https:// doi.org/10.1080/09637486.2017.1311844

Nayak, B., Liu, R.H. and Tang, J. (2015). Effect of Processing on Phenolic Antioxidants of Fruits, Vegetables, and Grains-A Review. Critical Reviews in Food Science and Nutrition, 55(7), 887918. https://doi.org/10.1080/10408398.2011.654142

Nugroho, D.A. and Aji, P. (2015). Characterization of Nata de Coco Produced by Fermentation of Immobilized Acetobacter xylinum. Agriculture and Agricultural Science Procedia, 3, 278-282. https:// doi.org/10.1016/j.aaspro.2015.01.053

Pa'e, N., Abd Hamid, N.I., Khairuddin, N., Zahan, K.A., Kok, F.S., Siddique, B.M. and Muhamad, I.I. (2014). Effect of Different Drying Methods on the Morphology, Crystallinity, Swelling Ability and Tensile Properties of Nata De Coco. Sains Malaysiana, 43(5), 767-773.

Phong, H.X., Lin, T.L., Thanh, N.N., Long, B.H.D. and Dung, N.T.P. (2017). Investigating the Conditions for Nata-de-Coco Production by Newly Isolated Acetobacter sp. Citation. American Journal of Food Science and Nutrition, 4(1), 1-6.

Pothakos, V., Illeghems, K., Laureys, D., Spitaels, F., Vandamme, P. and Vuyst, L.D. (2016). Acetic Acid Bacteria in Fermented Food and Beverage Ecosystems. in Acetic Acid Bacteria: Ecology and Physiology, p. 73-99. Tokyo, Japan: Springer Japan.

Sami, F. and Rahimah, S. (2015). Uji Aktivitas Antioksidan Ekstrakmetanol Bunga Brokoli (Brassica oleracea L. var. Italica) dengan Metode DPPH (2,2 diphenyl-1-picrylhydrazyl) dan Metode ABTS (2,2 azinobis (3-etilbenzotiazolin)-6-asam sulfonat). Jurnal Fitofarmaka Indonesia, 2(2), 107110. https://doi.org/10.33096/jffi.v2i2.179 [In
Bahasa Indonesia]

Srinivas, K., King, J.W., Howard, L.R. and Monrad, J.K. (2010). Solubility of Gallic Acid, Catechin, and Protocatechuic Acid in Subcritical Water from (298.75 to 415.85) K. Journal of Chemical and Engineering Data, 55(9), 3101-3108. https:// doi.org/10.1021/je901097n

Sugiyono. (2015). Metode Penelitian Kuantitatif, Kualitatif, R\&D. Bandung: CV. Alfabeta. [In Bahasa Indonesia]

Susrini. (2005). Index Efektifitas. Suatu Pemikiran Tentang Alternatif Untuk Memilih Perlakuan Terbaik pada Penelitian Pangan Fakultas Peternakan. 3rd ed. Malang: Universitas Brawijaya. [In Bahasa Indonesia]

Sutanto, A. (2012). Pineapple Liquid Waste As Nata De Pina Raw Material. Makara Seri Teknologi, 16(1), 63-67. https://doi.org/10.7454/mst.v16i1.1286 